\title{
Effects of soil moisture and length of irrigation on soil wetting to deliver fumigants through microirrigation lines in sandy spodosols
}

\author{
Bielinski M. Santos*, James P. Gilreath \\ Gulf Coast Research and Education Center, IFAS, University of Florida, Wimauma, USA; \\ *Corresponding Author: bmsantos@ufl.edu
}

Received 24 August 2011; revised 22 September 2011; accepted 13 October 2011.

\begin{abstract}
Soil fumigant delivery through microirrigation (drip) lines has the potential to replace direct soil injection into planting beds. However, wetting coverage in these Spodosols must be improved to increase soilborne pest and weed control. Field trials were carried out to determine the impact of soil moisture on the extent of wetting cross-sectional areas through varying irrigation times. Soil moisture contents were: 1) $7 \%$ moisture (field capacity), and 2) $20 \%$ (saturation), along with $2,4,6,8$, and $10 \mathrm{~h}$ of irrigation. Pressed beds had $70 \mathrm{~cm}$ tops. Drip lines had emitters spaced $30 \mathrm{~cm}$ apart delivering 0.056 $L \cdot \mathrm{min}^{-1}$ per $\mathrm{m}$ of row at $55 \mathrm{kPa}$, and two drip lines were buried at $2.5 \mathrm{~cm}$ below the surface and $30 \mathrm{~cm}$ apart from each other. Water was mixed with a blue marking dye to analyze the water distribution patterns. Beds were opened at the emitters and high-resolution digital pictures were taken for each treatment. Resulting images were adjusted using photographic software and covered areas across the beds were determined. Regression analysis showed significant quadratic equations for both soil moisture situations, with saturated soils obtaining the highest cross section coverage (90 and $94 \%$ after 8 and $10 \mathrm{~h}$ ). In field capacity beds, the maximum cross section coverage obtained was $82 \%$. Within each soil moisture situation, there were no differences between 8 and $10 \mathrm{~h}$ of irrigation.
\end{abstract}

Keywords: Methyl Bromide; Drip Irrigation; Soilborne Pests; Water Management

\section{INTRODUCTION}

The loss of methyl bromide (MBr) as soil fumigant has prompted a great deal of research to identify an alternative to use in horticultural crops. Thus far, combinations of broad-spectrum fungicides and nematicides followed by herbicides have been shown to be suitable options to reduce the impact of soilborne diseases, nematodes and weeds in vegetable crops. The conventional procedure to apply chemicals such as 1,3-dichloropropene + chloropicrin $(1,3-\mathrm{D}+\mathrm{Pic})$ and metam sodium $(\mathrm{MNa})$ has been either in-bed injections with chisels or pretransplant broadcast applications with specialized equipment [1]. However, the cost of the equipment and the risk of personnel poisoning are some of the concerns about these application techniques.

Application of any $\mathrm{MBr}$ alternative requires the maximum possible coverage of soil volume in order to contact the target pest in sufficient quantity and time duration to achieve acceptable control. Unfortunately, this is not always possible, thus pest control gaps are frequently observed. Therefore, more efficient delivery systems need to be developed. Some recent reports have indicated that strawberry yields obtained with $\mathrm{MBr}$ were comparable with those of Telone C-35 (1,3-D + Pic 65:35; Dow AgroSciences LLC, Indianapolis, Indiana, USA), Inline (1,3-D + Pic 61:33; Dow AgroSciences LLC, Indianapolis, Indiana, USA), liquid and granulated $\mathrm{MNa}$, Pic, methyl iodide, and methyl iodide + Pic $(60: 40)$. Other trials indicated that Inline ${ }^{\circledR}+\mathrm{MNa}, \mathrm{Te}-$ lone-C35 ${ }^{\circledR}+\mathrm{MNa}$, Telone II $^{\circledR}(98 \% 1,3$-D; Dow AgroSciences) $+\mathrm{MNa}$, and Telone-C $35^{\circledR}+\mathrm{MNa}+$ Bacilussubtilis were equivalent to $\mathrm{MBr}$ [2]. However, no much research has been conducted under Florida conditions on this subject and it needs to be further expanded.

The benefits of developing a soil fumigation system for light sandy soils, such as are present in Florida, could transcend current boundaries, allowing scientists to gain a better understanding of how fumigants move in the soil and their relationship with crop yields. Likewise, it would impact on the feasibility of vegetable crop set- 
tings, since costly injection machinery would not be needed for soil fumigation, because the same irrigation system used for delivery of water and fertilizer would be utilized. One of the biggest obstacles to many alternatives has been the onerous requirement for personal protective equipment (PPE). This PPE makes application even more difficult in subtropical climates because of the impact on workers. The possibilities of reducing soil and water pollution and personnel poisoning/exposure could be additional benefits derived from alternative delivery procedures.

Soil texture has a close relationship with waterfront movement in the soil profile. Heavy to loamy soils usually have slow vertical infiltration, providing greater opportunities for liquid formulations to move laterally, thus increasing coverage. However, in sandy soils, lateral movement of water is restricted by the large amount of macropores [3]. This has been the case for wetting pattern trials in Georgia, where distances of $45.7 \mathrm{~cm}$ between drip emitters provided the least bed width coverage, with the most occurring with $30 \mathrm{~cm}$ between emitters. The lowest uniformity of wetting took place with 40.6 and $45.7 \mathrm{~cm}$ between emitters, and a maximum wetting of $60 \%$ of the bed volume was obtained [4]. In Florida, irrigation duration trials resulted in $45 \%$ of the soil volume in the bed wetted after $12 \mathrm{~h}$ with a single drip tube, and $85 \%$ coverage after $10 \mathrm{~h}$ with two lines [5]. Likewise, irrigation volumes were tested and indicated that the use of two drip tubes only reduced the time of flooding, even though two drip tubes increased spatial distribution. The most bed wetting achieved with a single tube was $50 \%$ to $60 \%$, using $1135 \mathrm{~L}$ per $30 \mathrm{~m}$ of row [6,7]. Huckaba et al. [8] found that bed wetting with a single drip tape resulted in $50 \%$ coverage after $8 \mathrm{~h}$, while use of two tapes yielded $90 \%$ coverage.

To avoid erratic soilborne disease control with microirrigation, water application has to be studied considering the internal water movement in the soil profile. Research needs to be conducted to determine the optimum parameters for fumigant application through microirrigation systems in sandy soils. Distribution of irrigation water containing soil-active pesticides throughout the raised soil bed may be necessary to obtain adequate control of soilborne pests with microirrigation-applied chemicals. The objective of this research was to determine the impact of soil moisture on the extent of water coverage obtained through varying irrigation times.

\section{MATERIALS AND METHODS}

Two field trials were conducted during January and March 2003 at the Gulf Coast Research and Education Center (GCREC) of the University of Florida. The soils were classified as EauGallie fine sand (AlficHaplaquods, sandy, siliceous, hyperthermic) with $1.0 \%$ organic matter and $\mathrm{pH}$ 7.3. Raised beds were pressed with a bedder and covered with low-density plastic mulch. Bed dimensions were $0.71 \mathrm{~m}$ wide on top by $0.81 \mathrm{~cm}$ wide on the bottom by $0.20 \mathrm{~m}$ high, giving an approximate cross sectional area of $0.15 \mathrm{~m}^{2}$. Two drip irrigation lines (T-Tape Systems, San Diego, California, USA) will emitters spaced $30 \mathrm{~cm}$ apart were placed on bed tops before plastic mulch placement. Each emitter delivered $0.056 \mathrm{~L} \cdot \mathrm{m}^{-1}$ per minute at 0.55 bars. Drip lines were buried $2.5 \mathrm{~cm}$ below the surface and $30 \mathrm{~cm}$ apart.

Treatments were arranged in a split-plot design with three and six replications for January and March trials, respectively. Soil water contents were the main plots, while lengths of irrigation were the subplots. Water contents were $7 \%$ (field capacity) and 20\% (saturation). Lengths of irrigation were 2, 4, 6, 8, and $10 \mathrm{~h}$. Water table was maintained $0.45 \mathrm{~m}$ below bed surface by continuously providing seepage irrigation. Each experimental unit was $6 \mathrm{~m}$ long. Soil moisture levels were measured by weight at the beginning of each trial. Soil samples were collected at random from three places within each block and dried for $48 \mathrm{~h}$ at $120^{\circ} \mathrm{C}$.

Distribution of microirrigation water was evaluated by using a water-soluble blue marking dye. The $0.95 \mathrm{~L}$ of dye was mixed in a 208-L tank and was introduced into every tankful of water during the various irrigation cycles. This methodology has previously being tested and provides a quick, inexpensive, and readily visible method for evaluating patterns of microirrigation water distribution [4,5]. One week after dye application, plastic mulch was removed in two places within each experimental unit and cross sections were exposed at the emitters. In order to obtain darker cross sections, each cut was allowed to dry for $2 \mathrm{~h}$. Afterwards, high resolution digital pictures were taken of each section. Resulting images were transferred to photographic software and covered areas were analyzed and calculated. During preliminary trials, this digital methodology was adjusted to reduce image distortion. Also, this method was validated against a manual technique used previously, in which a Plexiglas grid is placed against the cross sections and the dye-marked contour is drawn [5]. The digital methodology proved to be more accurate and less time-consuming. The relationship between irrigation time and covered area was examined with regression analysis. Standard errors were used to measure differences among treatment means.

\section{RESULTS AND DISCUSSION}

There was no significant interaction between treatments and trial $(P>0.05)$. Therefore, data from the two trials were combined. Irrigation times significantly $(\mathrm{P}<$ 0.05) affected cross-sectional covered areas (Figure 1). 


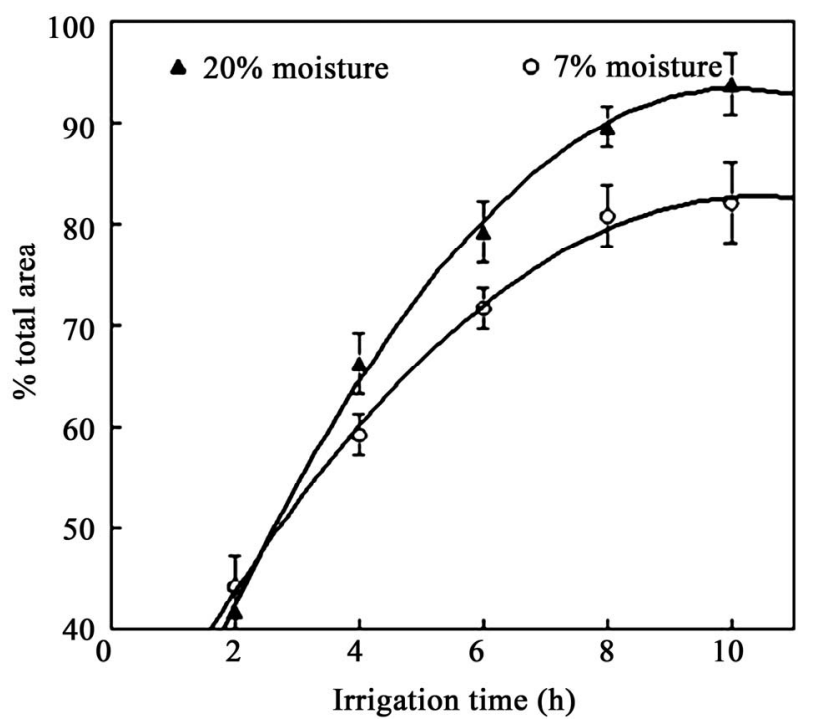

Figure 1. Effects of irrigation time on cross-sectional covered area of beds under two soil moisture contents. Regression equations are $\mathrm{y}=39.6+34.6 \mathrm{x}-1.6 \mathrm{x}^{2}, \mathrm{r}^{2}=0.91$ for $20 \%$ moisture; and $\mathrm{y}=55.0+27.6 \mathrm{x}-1.3 \mathrm{x}^{2}, \mathrm{r}^{2}=0.94$ for $7 \%$ moisture.

Quadratic regression equations characterized the responses of each soil moisture status $(y=39.6+34.6 x-$ $1.6 \mathrm{x}^{2}, \mathrm{r}^{2}=0.91$ for $20 \%$ moisture; and $\mathrm{y}=55.0+27.6 \mathrm{x}-$ $1.3 \mathrm{x}^{2}, \mathrm{r}^{2}=0.94$ for $7 \%$ moisture).

When irrigation was applied for $2 \mathrm{~h}$, no differences were observed in the wetted areas for either soil moisture, with less than $45 \%$ of total area wetting. However, significant changes were observed beginning with $4 \mathrm{~h}$ of irrigation. In those cases, beds with $20 \%$ moisture reached larger wetted areas at the emitters than those with $7 \%$ moisture. When $20 \%$ moisture was present, there were increments of $7 \%, 6 \%, 9 \%$, and $8 \%$ at $4,6,8$, and $10 \mathrm{~h}$ of irrigation, respectively. With the soil at field capacity and $10 \mathrm{~h}$ of irrigation, $82 \%$ wetting was obtained, whereas a maximum coverage of $94 \%$ was obtained in the saturated soil during the same period (Figure 1).

Previous reports on Florida Spodosols have indicated that the largest covered area obtained with two irrigation lines was $85 \%$ [5]. That finding was confirmed by these trials, where $82 \%$ wetting area was obtained under similar conditions. However, coverage was further improved by raising soil moisture prior to the irrigation. Therefore, soil water status has an influence on water distribution patterns throughout planting beds, increasing bed wet- ting as soil moisture increases.

This finding might allow scientists to redesign strategies for drip-applied fumigants in Florida Spodosols. Further studies should be conducted to determine if differences in wetting areas reflect positively on yields or soilborne pest and weed control. Also, the research should be conducted to assess the effect of increased wetting on fumigant diffusion beyond waterfronts.

\section{REFERENCES}

[1] Noling, J.W. and J.P. Gilreath (2001) Methyl bromide, progress and problems: Identifying alternatives to methyl bromide. University of Florida, Gainesville, 2.

[2] Ferguson, L.M., Fernández, G.E., Brannen, P.M., Louws, F.J., Poling, E.B., Sydorovych, O.B., Safley, C.D., Monks, D.W., Van Esbroeck, Z.P., Sanders, D.C. and Smith, J.P. (2001) Alternative soil treatments for strawberry in the southeastern United States. 2011 Annual International Research Conference on Methyl Bromide Alternatives and Emissions Reductions, San Diego, 5-9 November 2001, 42-1-4. http://www.mbao.org/

[3] Brady, N.C. (1990) The nature and properties of soils. MacMillan, New York.

[4] Csinos, A., Laska, J.E., Seebold, K. and Eger, J. (2001) Evaluation of microirrigation wetting patterns in polyethylene film mulch beds. 2001 Annual International Research Conference on Methyl Bromide Alternatives and Emissions Reductions, San Diego, 5-9 November 2001, 47-1-4. http://www.mbao.org/

[5] Eger, J.E., Gilreath, J.P. and Noling, J.W. (2001) Effect of irrigation times on wetting patterns in Florida vegetable soils. 2001 Annual International Research Conference on Methyl Bromide Alternatives and Emissions Reductions, San Diego, 5-9 November 2001, 48-1-4. http://www.mbao.org/

[6] Noling, J.W. and Gilreath, J.P. (2002) Crop destruction, crop residue and the importance of weed control for nematode management. Proceedings of Florida Agricultural Conference and Trade Show 2002, Lakeland, 22-23 May 2002, 45-46.

[7] Hu, T. and Desai, J.P. (2004) Soft-tissue material properties under large deformation: Strain rate effect. Proceedings of the 26th Annual International Conference of the IEEE EMBS, San Francisco, 1-5 September 2004, 27582761.

[8] Huckaba, R.M., Mueller, J.D. and Weiss, A.W. (2001) Effect of irrigation times on wetting patterns in Mid-Atlantic vegetable soils. 2001 Annual International Research Conference on Methyl Bromide Alternatives and Emissions Reductions, San Diego, 5-9 November 2001, 51-1-2. http://www.mbao.org/ 